\title{
Salinity Stress Alleviation by Foliar Bio-Stimulant, Proline and Potassium Nutrition Promotes Growth and Yield Quality of Garlic Plant
}

\author{
Eman F. A. Awad-Allah ${ }^{*}{ }^{*}$, Mona G. Attia ${ }^{2}$, Ahmed M. Mahdy ${ }^{1}$ \\ ${ }^{1}$ Soil and Water Sciences Department, Faculty of Agriculture, Alexandria University, Alexandria, Egypt \\ ${ }^{2}$ Ministry of Agriculture, Salinity and Alkalinity Soil Research Laboratory, Cairo, Egypt \\ Email: *dr.emanfadel@yahoo.com
}

How to cite this paper: Awad-Allah, E.F.A., Attia, M.G. and Mahdy, A.M. (2020) Salinity Stress Alleviation by Foliar Bio-Stimulant, Proline and Potassium Nutrition Promotes Growth and Yield Quality of Garlic Plant. Open Journal of Soil Science, 10, 443-458. https://doi.org/10.4236/ojss.2020.109023

Received: August 18, 2020

Accepted: September 26, 2020

Published: September 29, 2020

Copyright ( 2020 by author(s) and Scientific Research Publishing Inc. This work is licensed under the Creative Commons Attribution International License (CC BY 4.0).

http://creativecommons.org/licenses/by/4.0/

(c) (i) Open Access

\begin{abstract}
Soil salinity is one of the major yield-limiting factors for crop production in many agricultural regions all over the world. Besides following efficient management practices at the field scale to reduce accumulation of salts in the effective root-zone, the effective use of treatments to alleviate the effects of salinity stress and improve crop salt tolerance is a promising solution to ensure crop production in such adverse conditions. A field experiment was carried out to investigate the effect of foliar spray with plant-based biostimulant (i.e. with and/or without $3 \%$ yeast extract), three levels of proline $(0,25$, and 50 $\mathrm{mM}$ ), and combined with potassium fertilizers, as potassium sulfate, $48 \%$ $\mathrm{K}_{2} \mathrm{O}(0,50$, and $100 \mathrm{~kg} / \mathrm{fed}$.) on growth promotion, chemical composition of garlic leaves, bulb quality parameters as well as yield and its components of garlic plant grown under moderate saline soil. Results revealed that the interaction between foliar spray with yeast extract at $3 \%$ and proline at $50 \mathrm{mM}$ combined with proper $\mathrm{K}$ level at $100 \mathrm{~kg} / \mathrm{fed}$., was the best interaction treatment for increasing vegetative growth parameters, i.e. plant height, number of leaves per plant, and mineral contents ( $, \mathrm{P}, \mathrm{K}, \mathrm{S}, \mathrm{Ca}$ and $\mathrm{Mg}$ in leaves), and proline content of garlic leaves after 135 days from planting time, total yield/fed., and garlic yield quality parameters at harvesting time. In conclusion, the detrimental effects of salinity stress can be alleviated by stress tolerance-inducing compounds, such as yeast extract and proline with proper application rate of $\mathrm{K}$ fertilization during the growing season of garlic crop.
\end{abstract}

\section{Keywords}

Proline, Potassium, Yeast Extract, Garlic Plant, Salinity Stress, Soil Reclamation 


\section{Introduction}

Garlic (Allium sativum L.) is a species in the onion genus, Allium. It is a medicinal and exportable vegetable crop in Egypt that's grown for its distinctive taste and health benefits. Garlic has been used as a medicine throughout ancient and modern history and recently science has confirmed many of these beneficial health effects. Nutritional value and therapeutic potential of garlic have been taken to prevent and treat a wide range of conditions and diseases [1]. Garlic as a natural antibiotic has a broad-spectrum of actions; not only it is antibacterial, antiviral, antifungal and antiprotozoal, but it also has beneficial effects on the cardiovascular and boosts the function of the immune systems [1] [2]. Garlic is low in calories and rich in vitamin $\mathrm{C}$, vitamin $\mathrm{B}_{6}$, antioxidant, organo-sulphur compounds, manganese, trace amounts of various other nutrients, and it has a protective action against different types of cancer and the severity of common illnesses like the flu and common cold [3].

Soil salinity has a negative impact on food production in many countries of the world. Salinity destroys three hectares of arable land globally every minute and it is predicted that up to $30 \%$ of currently food-producing land may be lost within the next 25 years [4]. The most common reasons for salinization of the soil are poor soil-sustainable practices, excessive saline water irrigation and a severe usage of mineral fertilizers in arid and semi-arid climatic zones (characterized by high evapotranspiration, high temperature, and low rainfall) [5]. Thus, the salinity issue will remain one of the key threats to the global food production in the $21^{\text {st }}$ century [4]. The development of new strategies to alleviate salinity in plants and stimulate crop cultivation under salinity stress is a relevant research purpose to face the needs of a world with growing soil salinity issues [6].

Plants have developed various adaptation mechanisms at cellular, subcellular and organ levels for their nourishment under salt-affected soils [5]. Plants in salt-affected soils often have the same appearance as the plants growing under drought stress conditions although the plant wilting is much less prevalent due to the osmotic potential of the soil solution that usually changes gradually and plants adjust their internal salt content to maintain turgor and thus avoid wilting [7] [8].

Soil salinity management strategies have been evolved to enhance plant adaptation capability or tolerance to salinity stress, such as development of salt-tolerant genotypes, exogenous application of compatible solutes (either as aerial sprays, or seed priming), like proline and other bio-stimulants (e.g. yeast extract), proper use of $\mathrm{K}$ and $\mathrm{Zn}$ fertilization with organic amendment, and use of fresh water as a safe source of irrigation for agricultural purposes, with following effective management practices to mitigate the adverse effects of salinity-induced oxidative stress [6] [9].

Therefore, objectives of the current research were to investigate stress tolerance-inducing compounds by studying the effect of foliar spray with bio-stimulant (i.e. $3 \%$ yeast extract), and proline in combined with proper po- 
tassium nutrition on growth promotion and yield quality of garlic (Allium sati$\operatorname{vum}(\mathrm{L}$.) $c v$. Sids-40) grown under moderate saline soil.

\section{Materials and Methods}

\subsection{Experimental Site and Soil Properties}

The field experiments were conducted at the experimental farm of the soil salinity and alkalinity laboratory at Alexandria during the growing season of garlic cv. Sids- 40 . This site lies between latitude $31^{\circ} 2^{\prime \prime} \mathrm{N}$, and longitude $29^{\circ} 6^{\prime \prime} \mathrm{E}$ with an elevation of about $2.50 \mathrm{~m}$ below sea level. The annual rainfall averaged $200 \mathrm{~mm}$ and the relative humidity during daytime is about $67.30 \%$ at the experimental site. The mean maximum temperature during August and September ranged between $30.9^{\circ} \mathrm{C}$ and $29.6^{\circ} \mathrm{C}$.

\subsubsection{Physio-Chemical Properties of the Experimental Soil Location}

The physical and chemical characteristics of surface $(0-30 \mathrm{~cm})$ soil samples were analyzed before planting garlic cloves. Composite surface soil samples were air-dried, ground and passed through $2 \mathrm{~mm}$ sieve pores, and stored at room temperature for analysis.

Electrical conductivity (EC), soluble cations and anions were measured in the soil paste extracts according to Page et al. [10]. The soil $\mathrm{pH}$ was measured in soil: water suspension (1:2.5) according to McLean, [11]. Soil organic matter content was determined by Walkley-Black method [10]. Total calcium carbonate (\%Ca$\mathrm{CO}_{3}$ ) was estimated by Calcimeter Method according to Horváthet al. [12].

Available nitrogen $\left(\mathrm{NH}_{4}-\mathrm{N}\right.$ and $\left.\mathrm{NO}_{3}-\mathrm{N}\right)$ was extracted by $2 \mathrm{M} \mathrm{KCl}$ and determined by Jones Jr [13]. The Available phosphorus was determined by Olsen's sodium bicarbonate method $\left(0.5 \mathrm{M} \mathrm{NaHCO}_{3}, \mathrm{pH} 8.5\right)$ according to Jones Jr [13] and soluble phosphorus in solution was measured colorimetrically (spectrophotometer) by the ascorbic acid molybdenum-blue method [14]. Available K was extracted by ammonium acetate $(1 \mathrm{~N}, \mathrm{pH} 7)$ and measured by the flame photometer [13]. The physical and chemical properties of soil samples are shown in Table 1.

\subsubsection{Chemical Analysis of the Irrigation Water}

Irrigation water samples were collected from the main irrigation canal, and then samples were sent for chemical analysis at Department of Soil and Water Sciences, Faculty of Agriculture, Alexandria University. The chemical analysis of water samples is shown in Table 2.

\subsection{Experimental Design}

The experimental layout used was Randomized Complete Block Design (RCBD) with three replicates. Each experimental unit consisted of three rows, $4 \mathrm{~m}$ long and $50 \mathrm{~cm}$ in width spacing between plants was $10 \mathrm{~cm}$. The experimental site was irrigated, one excess irrigation, by flooding before planting (15 days) to leach salts below the root zone.

Cloves of garlic (Allium sativum (L.) cr. Sids-40) were selected for nearly 
Table 1. Physico-chemical properties of the experimental soil location.

\begin{tabular}{ll}
\hline Parameters & Values \\
\hline Physical properties: & \\
Sand $(0.2-0.02 \mathrm{~mm})$ & $39 \% \pm 0.51 \%$ \\
Silt $(0.02-0.002 \mathrm{~mm})$ & $29 \% \pm 0.63 \%$ \\
Clay $(<0.002 \mathrm{~mm})$ & $32 \% \pm 0.72 \%$ \\
Texture & Clay loam \\
Chemical properties: & \\
pH & $7.73 \pm 0.02$ \\
EC & $4.03 \pm 0.11 \mathrm{dS} \cdot \mathrm{m}^{-1}$ \\
Organic Matter $(\mathrm{OM})$ & $2.06 \% \pm 0.5 \%$ \\
CEC & $23 \pm 0.25 \mathrm{Cmol} \cdot \mathrm{kg}^{-1}$ \\
CaCO & \\
${ }^{*}$ ESP & $7.4 \% \pm 0.16 \%$ \\
SAR & $8.13 \% \pm 0.21 \%$ \\
Available-N & $6.85 \pm 0.43$ \\
Olsen-P & $30.22 \pm 1.5 \mathrm{mg} \cdot \mathrm{kg}^{-1}$ \\
Available-K & $8.11 \pm 0.19 \mathrm{mg} \cdot \mathrm{kg}^{-1}$ \\
\hline
\end{tabular}

${ }^{*}$ ESP, The exchangeable sodium percent was calculated from sodium adsorption; ratio (SAR), 'Data is average of 3 replicates \pm standard deviation $(\mathrm{SD})$.

Table 2. Chemical analysis of the irrigation water used in the study.

\begin{tabular}{|c|c|c|c|c|c|c|c|c|c|c|}
\hline \multirow{2}{*}{ Irrigation } & \multirow{2}{*}{$\begin{array}{c}\mathrm{EC} \\
\left(\mathrm{dSm}^{-1}\right)\end{array}$} & \multirow{2}{*}{$\mathrm{pH}$} & \multicolumn{7}{|c|}{ Cation and anion concentration (meq. $\mathrm{L}^{-1}$ ) } & \multirow{2}{*}{ SAR } \\
\hline & & & $\mathrm{Ca}^{2+}$ & $\mathrm{Mg}^{2+}$ & $\mathrm{K}^{+}$ & $\mathrm{Na}^{+}$ & $\mathrm{HCO}_{3}^{-}$ & $\mathrm{Cl}^{-}$ & $\mathrm{SO}_{4}^{2-}$ & \\
\hline Canal water & $0.60 \pm 0.01$ & 7.15 & $\ddagger_{2} 2.01 \pm 0.05$ & $1.70 \pm 0.03$ & $0.28 \pm 0.05$ & $2.10 \pm 0.10$ & $1.42 \pm 0.07$ & $3.39 \pm 0.10$ & $1.19 \pm 0.05$ & 1.54 \\
\hline IWC & $<0.7$ & $6.5-8.4$ & $<3$ & $<3$ & $<0.30$ & $<3$ & $<1.5$ & $<4$ & $<1.2$ & $<3$ \\
\hline
\end{tabular}

${ }^{\ddagger}$ Means of three samples \pm SD.

IWC: Irrigation water criteria, EPA, USA [15].

uniform in shape and size, treated with fungicides and hand-planted in the row on September $20^{\text {th }}, 2018$.

Proline foliar treatment was applied using an ordinary sprayer with a sharp nozzle. Three levels of proline namely 0,25 , and $50 \mathrm{mM}$ considered as Pro 0, Pro 1 , and Pro 2, respectively, were prepared in distilled water containing $0.1 \%$ Tween ${ }^{\circledR} 20$ as a non-ionic surfactant, as well as control (sprayed with tap water). All foliar treatments were applied three times at 30, 45, 60 days after sowing.

Potassium fertilizer was added in soil during the vegetative growth stage (60 days after cultivation) using potassium sulfate $\left(48 \% \mathrm{~K}_{2} \mathrm{O}\right)$, whereas potassium levels as, $\mathrm{K} 0$ (control or no potassium), $\mathrm{K} 1$ (50 kg/fed.), and $\mathrm{K} 2$ (100 kg/fed.). Phosphorus fertilizer was applied using calcium superphosphate $\left(15.5 \% \mathrm{P}_{2} \mathrm{O}_{5}\right)$ at a rate of $(75 \mathrm{~kg} / \mathrm{fed}$.) during soil preparation. Nitrogen fertilizer was added in the 
form of ammonium nitrate $(33.5 \% \mathrm{~N})$ at a rate of $(100 \mathrm{~kg} \mathrm{~N} / \mathrm{fed}$.) in two equally separated doses, one at the time of planting and the other during the vegetative growth stage (75 days after cultivation). All other agricultural practices were performed as recommended for garlic production according to the recommendations of the Egyptian Ministry of Agriculture.

This experiment included 18 treatments, which included two foliar bio-stimulant treatments (i.e. with and/or without 3\% yeast extract), and all combinations between the three levels of potassium fertilizers $(0,50$, and $100 \mathrm{~kg} / \mathrm{fed}$.) with three foliar spraying of proline levels $(0,25$, and $50 \mathrm{mM})$.

Yeast extract (YE) 3\% was prepared from active dry yeast (Saccharomyces cerevisiae) according to the modified method of Francesca et al. [16] by dissolving amount of dry yeast in water followed by adding sugar (as a source of $\mathrm{C}$ and $\mathrm{N}$ ) at a ratio of 1:1 and kept 24 hours in a warm place for activation before application on the plants. Yeast extract is rich in beneficial bioconstituents such as amino acids, peptides, phytohormones, vitamins, carbohydrates, trace elements, and other growth factors....etc., hence making it suitable for foliar application. The nutritional contents of the yeast extract are shown in Table 3.

Table 3. The nutritional contents of the yeast extract.

\begin{tabular}{|c|c|c|c|c|c|}
\hline \multicolumn{2}{|c|}{ Minerals (mg/g) } & \multicolumn{2}{|c|}{ Amino acids (mg/100g) } & \multicolumn{2}{|c|}{ Vitamins (mg/100g) } \\
\hline $\mathrm{K}$ & $23.0 \pm 0.05^{\star}$ & Arginine & $2.18 \pm 0.07$ & Vitamin B1 & $3.25 \pm 0.03$ \\
\hline $\mathrm{P}$ & $16.0 \pm 0.12$ & Aspartic acid & $1.46 \pm 0.12$ & Vitamin B2 & $1.92 \pm 0.10$ \\
\hline $\mathrm{Ca}$ & $0.84 \pm 0.06$ & Glutamic acid & $2.20 \pm 0.24$ & Vitamin B6 & $1.63 \pm 0.23$ \\
\hline $\mathrm{Mg}$ & $1.78 \pm 0.21$ & Histidine & $2.89 \pm 0.09$ & Vitamin B12 & $0.55 \pm 0.01$ \\
\hline $\mathrm{S}$ & $4.70 \pm 0.13$ & Isoleucine & $2.44 \pm 0.13$ & & \\
\hline $\mathrm{Fe}$ & $0.07 \pm 0.14$ & Leucine & $3.15 \pm 0.21$ & & \\
\hline $\mathrm{Si}$ & $0.12 \pm 0.05$ & Lysine & $2.99 \pm 0.02$ & & \\
\hline $\mathrm{Zn}$ & $0.21 \pm 0.10$ & Methionine & $0.83 \pm 0.14$ & & \\
\hline $\mathrm{Mn}$ & $0.05 \pm 0.09$ & Proline & $1.65 \pm 0.10$ & & \\
\hline $\mathrm{Cu}$ & $8.90 \pm 0.15$ & Serine & $1.74 \pm 0.13$ & & \\
\hline Mo & $0.55 \pm 0.21$ & Valine & $2.33 \pm 0.11$ & & \\
\hline
\end{tabular}

${ }^{\star}$ Means of three samples \pm SD.

The treatments with $3 \%$ yeast extract were applied four times, and the first one was 65 days from planting and repeated each 15 days intervals. The plants were sprayed using a small motor sprayer, with uniform coverage until run-off, with a wetting agent Tween ${ }^{\circledR} 20(0.1 \%)$ added to the spraying solution. Treatments without $3 \%$ yeast extract, plants were sprayed with fresh water.

\subsection{Measurements}

\subsubsection{Vegetative Growth Parameters of Garlic}

Three plants were randomly selected from each experimental plot after 135 days 
of planting, to assess vegetative growth parameters, i.e. plant height $(\mathrm{cm})$, number of leaves per plant.

\subsubsection{Nutritional and Chemical Composition of Garlic Leaves}

Plant leaves were sampled and separated into two groups; one was kept fresh to determine proline content according to the method of Bates et al. [17]. The results were expressed as $\mathrm{mg} / \mathrm{g}$ of proline equivalent of the fresh weight of the samples. The other group of leaves samples were oven dried at $70^{\circ} \mathrm{C}$ for $48 \mathrm{~h}$, and $\mathrm{N}, \mathrm{P}, \mathrm{K}, \mathrm{Ca}, \mathrm{Mg}$ and $\mathrm{S}$ contents were estimated. Total nitrogen content was determined according to the method described by Jones Jr [13]. While, total phosphorus content was measured according to Page et al. [10]. Also, total potassium content was determined according to the method described by Jones Jr, [13]. Calcium and Magnesium contents were measured according to Jackson, [18]. Sulfur content was determined according to the methods described by Johnson and Nishita [19].

\subsubsection{Garlic Yield Quality Parameters}

The irrigation treatments were cut off before 15 days from harvesting date. The bulbs were harvested at full maturity stage (180 days from planting) with three samples of each experimental plot; a description of morphological and quality features of bulbs was carried out. The recorded features were bulb diameter $(\mathrm{cm})$, weight of bulb per plant $(\mathrm{g})$, number of cloves per bulb, average clove weight (g), total yield (ton/fed.). Relative total yield (\%) was calculated according to the following equation:

$$
\text { Relative total yield }(\%)=\left[T_{1} / T_{2}\right] \times 100
$$

where:

$$
T_{1}=\text { Total yield of treatment, } T_{2}=\text { Total yield of control } \text {. }
$$

\subsection{Statistical Analyses}

The data obtained were subjected to analysis of variance (ANOVA) according to Gomez and Gomez [20], using CoStat Software Program Version 6.303 [21], and LSD at 0.05 level of significance was used for the comparison between means.

\section{Results and Discussion}

The present study is exploring alleviation strategies of salinity stress for promoting growth and yield quality of garlic plant grown under moderate saline soil through foliar spray with bio-stimulant (i.e. 3\% yeast extract), proline and proper potassium nutrition. Physical and chemical properties of the studied soil are presented in Table 1. Data showed that soil has a fine-textured, where the clay content was found to be $32 \% \pm 0.72 \%$ and the texture class is clay loam. Data in Table 1 revealed that the studied soil type was moderate saline-non sodic, where measured soil EC was $4.03 \% \pm 0.11 \mathrm{dSm}^{-1}$ and ESP was $8.13 \% \pm 0.21 \%$.

Chemical analysis of the irrigation water used in this study comparing with irrigation water standards are presented in Table 2. Canal water with $\mathrm{EC}=0.60 \pm$ 
$0.01 \mathrm{dSm}^{-1}$ is available for surface irrigation technique used at the Experimental Research Station area and there is no restriction on usage for crop irrigation according to Irrigation Water Criteria (IWC) [15].

In a uniform field having moderate salinity, it can often go undetected because it causes no apparent injuries other than restricted plant growth [7]. In this case, soil reclamation by following efficient management practices at the field scale can reduce accumulation of salts in the effective root-zone [6]. One excess irrigation by flooding before planting (15 days) for leaching salts below the root zone is a viable method for reclamation of saline bare soil and crop production [22] [23]. The current study shows that, although garlic tends to be slightly more salt tolerant than most vegetable crops, the need to maintain low soil salinity levels is essential for maximum yield.

\subsection{Vegetative Growth Parameters of Garlic}

Figure 1 shows the effect of different treatments of proline, $\mathrm{K}$ levels, and their interactions without and/or with 3\% yeast extract on the studied vegetative growth parameters, i.e. plant height, and number of leaves per plant at 135 days after planting time. The obtained results showed that garlic plant height was significantly increased with increasing proline and $\mathrm{K}$ levels without yeast extract (Figure 1(A)) and/or with 3\% yeast extract (Figure 1(B)). Data revealed that garlic plants grown under salinity stress and sprayed with $3 \%$ yeast extract had better vegetative growth than those unsprayed. Foliar spray with (i.e. $3 \%$ yeast extract) had a beneficial effect on plant growth promotion and final crop quality. It was found that yeast extract treatment had the ability to induce significant recovery for the reduction in vegetative growth of garlic plants grown under moderate saline soil.

Plant-based biostimulant (i.e. yeast extract), which is environmentally friendly, nutritious, and convenient to use, has advantages over common plant growth regulators and soil conditioners [24]. The improvement of plants growth in response to the foliar application of active dry yeast may be attributed to its nutritional contents of different nutrients, a relatively larger proportion of amino acids, higher percentage of peptides, phytohormones, higher values of vitamins, carbohydrates, trace elements, and other growth factors (Table 3). Many studies indicated that yeast has stimulatory effects on cell division, elongation, enlargement, chlorophyll formation, protein and nucleic acid synthesis [16] [25]. It was found that the simulative effect of yeast extract treatment can recover the reduction occurred in vegetative growth of leucaena plants which exposed to salinity stress [26].

The interaction effect between proline foliar applications and $\mathrm{K}$ treatments had significant effect on different vegetative growth parameters than control treatment without yeast extract (Figure 1(A) \& Figure 1(C)) and/or with 3\% yeast extract (Figure 1(B) \& Figure 1(D)). In this respect, the plants which sprayed with $3 \%$ yeast extract, Pro $2(50 \mathrm{mM})$, and $\mathrm{K} 2(100 \mathrm{~kg} / \mathrm{fed}$.) resulted in 


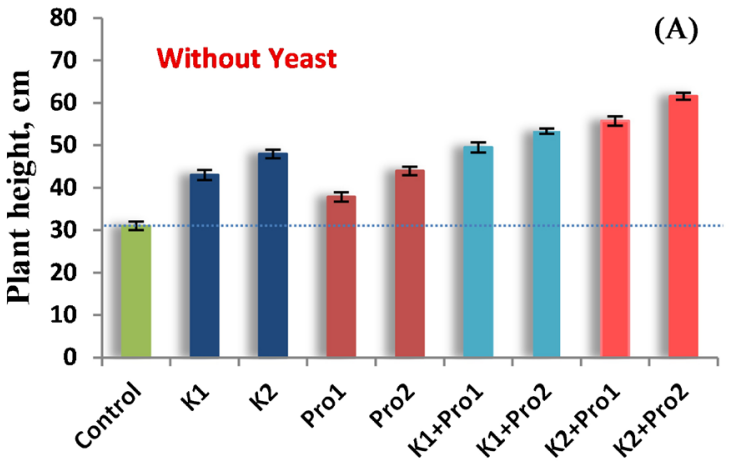

Treatments

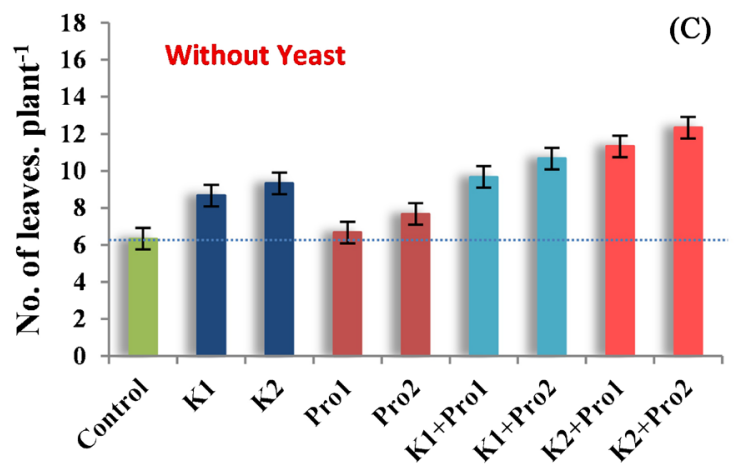

Treatments

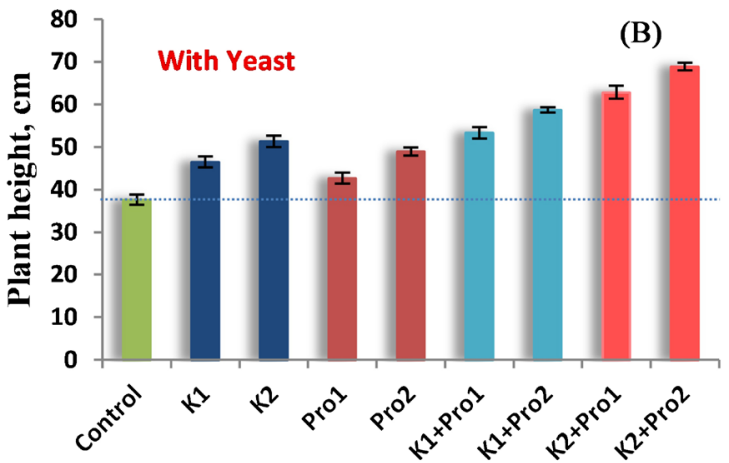

Treatments

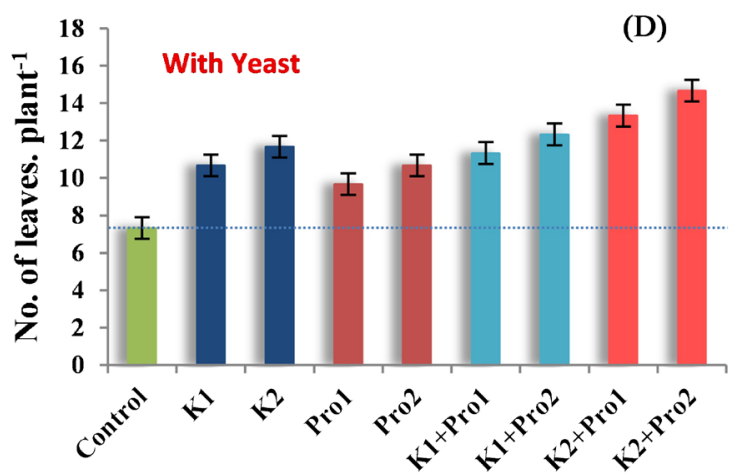

Treatments

Figure 1. Plant height ((A) \& (B)), and no. of leaves per plant ((C) \& (D)) of garlic plants at 135 days after planting time as affected by proline, $\mathrm{K}$ levels, and their interactions without yeast ((A) \& (C)), and with $3 \%$ yeast ((B) \& (D)) during growing season. Error bars represent standard deviation of the mean.

the highest values of plant height as well as number of leaves per plant at 135 days after planting time.

Scientists reported that treatment of sweet pepper with stress tolerance-inducing compounds alleviates salinity stress oxidative damage by mediating the physio-biochemical activities and antioxidant systems. Further, it was found that the important role of proline, salicylic acid, and yeast extracts in enhancing sweet pepper growth and tolerance to salinity stress via modulation of the physiological parameters and antioxidants machinery. Interestingly, proline proved to be the best treatment [27].

Proline is a compatible organic solute that accumulated in the cytoplasm of the plant cells growing in saline environments [6]. Furthermore, proline has a positive impact on the activity of enzymes and osmotic adjustment under stress conditions, while protecting enzyme against denaturation or inhibition of activity [27] [28]. The exogenous application of proline has been suggested to be an effective approach in improving crop salt tolerance in higher plants [28].

\subsection{Nutritional and Chemical Composition of Garlic Leaves}

Data in Table 4 show the interaction effect between yeast extract (3\%), $\mathrm{K}$ and proline treatments on chemical composition and proline content of garlic leaves at 135 days after planting time. It is obvious that all chemical constituents of 
leaves such asN, P, K, S, Ca and Mg contents as well as proline content of garlic leaves were significantly affected by sprayed plants with both yeast extract, and proline in combination with $\mathrm{K}$ nutrition than control treatment. In this respect, the plants which sprayed with yeast extract at $3 \%$ yeast extract, Pro $2(50 \mathrm{mM})$, and $\mathrm{K} 2(100 \mathrm{~kg} / \mathrm{fed}$.) achieved the highest concentrations of $\mathrm{N}, \mathrm{P}, \mathrm{K}, \mathrm{S}, \mathrm{Ca}$ and $\mathrm{Mg}$ in leaves as well as proline content in garlic leaves at 135 days after planting time.

Table 4. Interaction effect between yeast extract (3\%), $\mathrm{K}$ and proline treatments on chemical composition, and proline content of garlic leaves.

\begin{tabular}{|c|c|c|c|c|c|c|c|c|c|}
\hline \multicolumn{3}{|c|}{ Treatments } & $\mathrm{N}$ & $\mathrm{P}$ & K & S & $\mathrm{Ca}$ & $\mathrm{Mg}$ & \multirow{2}{*}{$\begin{array}{c}\text { Proline } \\
(\mathrm{mg} / \mathrm{g} \text { F.W })\end{array}$} \\
\hline $\begin{array}{c}\text { Yeast Extract } \\
(3 \%)\end{array}$ & $\begin{array}{c}\mathrm{K} \\
(\mathrm{kg} / \mathrm{fed} .)\end{array}$ & $\begin{array}{c}\text { Proline } \\
(\mathrm{mM})\end{array}$ & \multicolumn{6}{|c|}{ (\%) } & \\
\hline \multirow[t]{9}{*}{ Without yeast } & K0 & Pro 0 & $1.33^{1}$ & $0.14^{\mathrm{m}}$ & $1.22^{\circ}$ & $0.20^{\mathrm{n}}$ & $0.55^{\circ}$ & $0.10^{\circ}$ & $30.2^{\mathrm{q}}$ \\
\hline & & Pro 1 & $1.69^{\mathrm{ij}}$ & $0.16^{1}$ & $1.28^{\mathrm{n}}$ & $0.25^{\mathrm{m}}$ & $0.58^{\mathrm{n}}$ & $0.12^{\mathrm{n}}$ & $40.2^{1}$ \\
\hline & & Pro 2 & $1.73^{\mathrm{i}}$ & $0.18^{\mathrm{k}}$ & $1.34^{\mathrm{m}}$ & $0.29^{\mathrm{k}}$ & $0.60^{\mathrm{m}}$ & $0.13^{\mathrm{m}}$ & $43.5^{j}$ \\
\hline & K1 & Pro 0 & $1.64^{\mathrm{jk}}$ & $0.20^{j}$ & $1.40^{1}$ & $0.30^{\mathrm{k}}$ & $0.63^{1}$ & $0.16^{\mathrm{k}}$ & $33.6^{\mathrm{p}}$ \\
\hline & & Pro 1 & $1.82^{\mathrm{gh}}$ & $0.24^{\mathrm{g}}$ & $1.46^{j}$ & $0.35^{\mathrm{h}}$ & $0.66^{\mathrm{i}}$ & $0.20^{\mathrm{gh}}$ & $46.5^{\mathrm{h}}$ \\
\hline & & Pro 2 & $2.03^{\mathrm{f}}$ & $0.26^{\mathrm{ef}}$ & $1.50^{\mathrm{i}}$ & $0.38^{\mathrm{g}}$ & $0.68^{\mathrm{h}}$ & $0.21^{\mathrm{g}}$ & $50.5^{\mathrm{g}}$ \\
\hline & $\mathrm{K} 2$ & Pro 0 & $2.17^{\mathrm{de}}$ & $0.22^{\mathrm{h}}$ & $1.60^{\mathrm{g}}$ & $0.40^{\mathrm{f}}$ & $0.69^{g}$ & $0.17^{j}$ & $36.2^{\circ}$ \\
\hline & & Pro 1 & $2.25^{\mathrm{cd}}$ & $0.28^{\mathrm{d}}$ & $1.72^{\mathrm{d}}$ & $0.43^{\mathrm{e}}$ & $0.71^{\mathrm{e}}$ & $0.23^{e}$ & $52.4^{\mathrm{e}}$ \\
\hline & & Pro 2 & $2.31^{\mathrm{c}}$ & $0.30^{c}$ & $1.88^{\mathrm{b}}$ & $0.46^{\mathrm{cd}}$ & $0.72^{\mathrm{d}}$ & $0.25^{\mathrm{c}}$ & $55.6^{c}$ \\
\hline \multirow[t]{9}{*}{ With yeast } & K0 & Pro 0 & $1.56^{\mathrm{k}}$ & $0.17^{1}$ & $1.30^{\mathrm{n}}$ & $0.28^{1}$ & $0.60^{\mathrm{m}}$ & $0.14^{1}$ & $34.2^{\mathrm{p}}$ \\
\hline & & Pro 1 & $1.75^{\mathrm{hi}}$ & $0.19^{\mathrm{k}}$ & $1.39^{1}$ & $0.32^{j}$ & $0.64^{\mathrm{k}}$ & $0.19^{\mathrm{i}}$ & $42.4^{\mathrm{k}}$ \\
\hline & & Pro 2 & $1.86^{\mathrm{g}}$ & $0.21^{\mathrm{i}}$ & $1.44^{\mathrm{k}}$ & $0.34^{\mathrm{i}}$ & $0.65^{j}$ & $0.20^{\mathrm{h}}$ & $45.5^{\mathrm{i}}$ \\
\hline & K1 & Pro 0 & $1.91^{\mathrm{g}}$ & $0.23^{\mathrm{g}}$ & $1.49^{\mathrm{i}}$ & $0.36^{\mathrm{h}}$ & $0.66^{\mathrm{i}}$ & $0.21^{\mathrm{g}}$ & $37.1^{\mathrm{n}}$ \\
\hline & & Pro 1 & $2.00^{\mathrm{f}}$ & $0.27^{\mathrm{e}}$ & $1.55^{\mathrm{h}}$ & $0.42^{\mathrm{e}}$ & $0.70^{\mathrm{ef}}$ & $0.24^{\mathrm{d}}$ & $51.6^{\mathrm{f}}$ \\
\hline & & Pro 2 & $2.12^{\mathrm{e}}$ & $0.29^{\mathrm{d}}$ & $1.67^{\mathrm{f}}$ & $0.45^{\mathrm{d}}$ & $0.73^{c}$ & $0.26^{\mathrm{c}}$ & $53.1^{\mathrm{d}}$ \\
\hline & $\mathrm{K} 2$ & Pro 0 & $2.20^{\mathrm{de}}$ & $0.25^{\mathrm{f}}$ & $1.70^{\mathrm{e}}$ & $0.47^{\mathrm{bc}}$ & $0.70^{\mathrm{f}}$ & $0.22^{\mathrm{f}}$ & $39.4^{\mathrm{m}}$ \\
\hline & & Pro 1 & $2.40^{\mathrm{b}}$ & $0.32^{\mathrm{b}}$ & $1.85^{\mathrm{c}}$ & $0.48^{\mathrm{b}}$ & $0.74^{\mathrm{b}}$ & $0.27^{\mathrm{b}}$ & $56.5^{\mathrm{b}}$ \\
\hline & & Pro 2 & $2.54^{\mathrm{a}}$ & $0.37^{\mathrm{a}}$ & $2.03^{\mathrm{a}}$ & $0.54^{\mathrm{a}}$ & $0.76^{\mathrm{a}}$ & $0.29^{\mathrm{a}}$ & $58.6^{\mathrm{a}}$ \\
\hline
\end{tabular}

Means in each column, followed by the same alphabetical letter(s) in common, are not significantly different at $p \leq 0.05$.

Among the plant nutrients, $\mathrm{K}$ is a very important nutrient for increasing garlic yields and obtaining optimal production levels [29]. Proper application rates and 
timing are critical for generating a yield, high quality response, and good storage ability of garlic. As crop yields increase, the amount of $\mathrm{K}$ required also increases, along with all other nutrients [29] [30]. In recent decades, $\mathrm{K}$ was found to provide abiotic stress tolerance in plants. However, the exact mechanisms of these protections are still under investigation [31]. Under salt stress, sufficient level of $\mathrm{K}$ helps to maintain ion homeostasis and to regulate the osmotic balance. In addition, $\mathrm{K}$ can enhance antioxidant defense in plants and therefore protects them from oxidative stress under various environmental adversities. Furthermore, $\mathrm{K}$ provides some cellular signaling alone or in association with other signaling molecules and phytohormones [31].

Scientists reported that the uptake of different nutrients by garlic plant varied significantly due to the different application levels of $\mathrm{K}$. Potassium alone induced maximum uptake of all the elements studied $(\mathrm{N}, \mathrm{P}, \mathrm{K}, \mathrm{S}, \mathrm{Ca}, \mathrm{Mg}, \mathrm{B}$, and $\mathrm{Na}$ ) at $\mathrm{K}$ at $200 \mathrm{~kg} \cdot \mathrm{ha}^{-1}$ and the lowest in control $\mathrm{K} 0$ treatment [29]. It was found that these essential and beneficial nutrients could protect crop plants against both abiotic and biotic stresses by enhancing the plant resistance power and regulating the mineral nutritional status [32].

Proline accumulation is a common physiological response in many plants in response to a wide range of biotic and abiotic stresses [33]. It is obvious from data presented in Table 4 that proline had markedly accumulated in garlic leaves; the highest concentration was recorded with 3\% yeast extract, Pro 2 (50 $\mathrm{mM})$, and $\mathrm{K} 2$ (100 kg/fed.) in comparison to the control plants during growing season. Proline concentration was significantly increased in response to salt-stress conditions. This increment represents an important mechanism to minimize the deleterious impact of salinity stress and enhance plant growth [33]. Indeed, overproduction of proline in plants induces stress tolerance by maintaining cell turgor or osmotic balance; stabilizing membranes, thereby preventing electrolyte leakage; and bringing concentrations of reactive oxygen species (ROS) within normal ranges, thus preventing oxidative bursts [34].

\subsection{Garlic Yield Quality Parameters}

Figure 2 \& Figure 3 show the effect of different K levels, proline, and their interactions without and/or with $3 \%$ yeast extract on garlic yield quality parameters, i.e. average clove weight, number of cloves per bulb, weight of bulb per plant, bulb diameter, total yield, and relative total yield of garlic plants at 180 days after planting time.

The obtained results from Figure 2 showed that all bulb quality parameters i.e. average clove weight, number of cloves per bulb, weight of bulb per plant, and bulb diameter were significantly increased with increasing $\mathrm{K}$ levels without yeast extract ((A), (C), (E) \& (G)), and/or with $3 \%$ yeast ((B), (D), (F) \& (H)) at harvesting time. Figure 2 revealed that the interaction between $\mathrm{K}$ level, proline, and $3 \%$ yeast extract had significant effect on all bulb quality parameters than control, and the interaction between the highest rate of $\mathrm{K}$ level (100 kg/fed.), and 


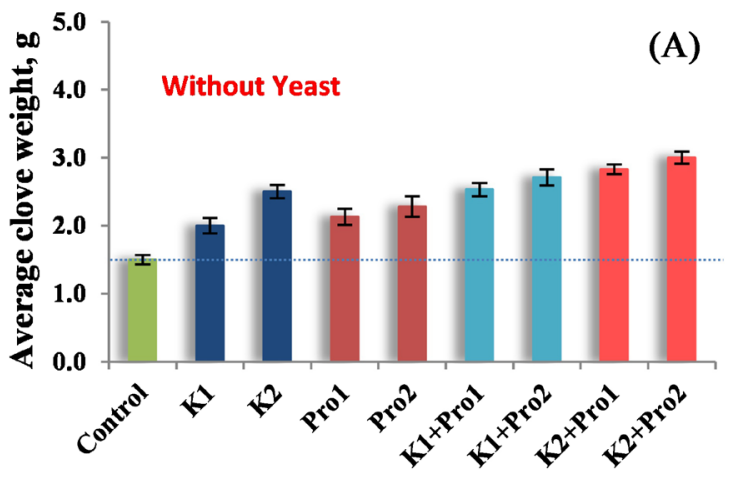

Treatments

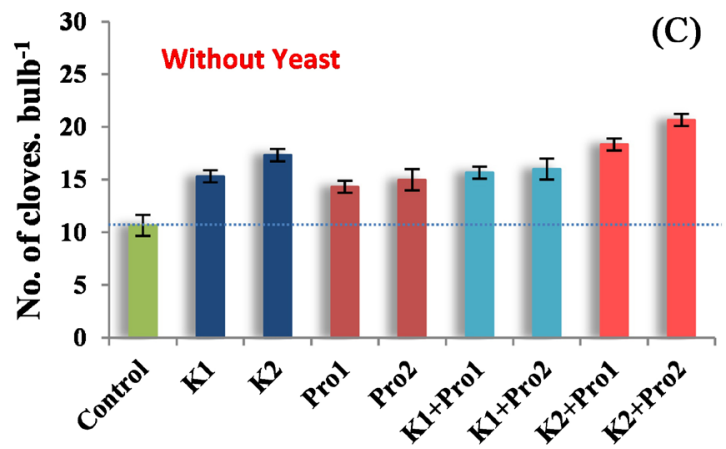

Treatments

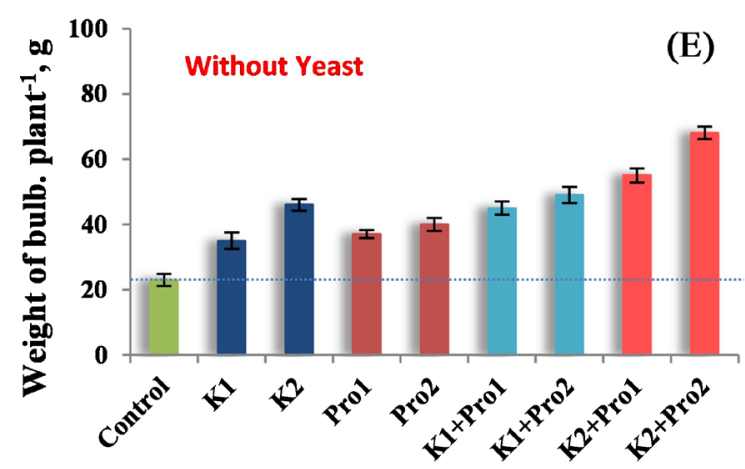

Treatments

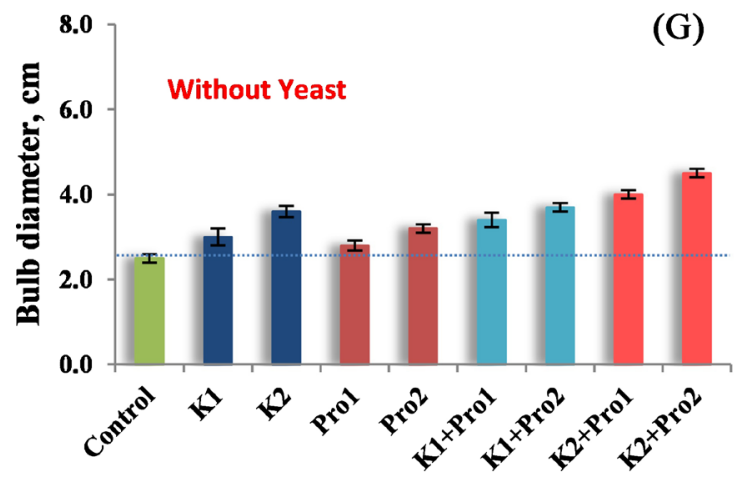

Treatments

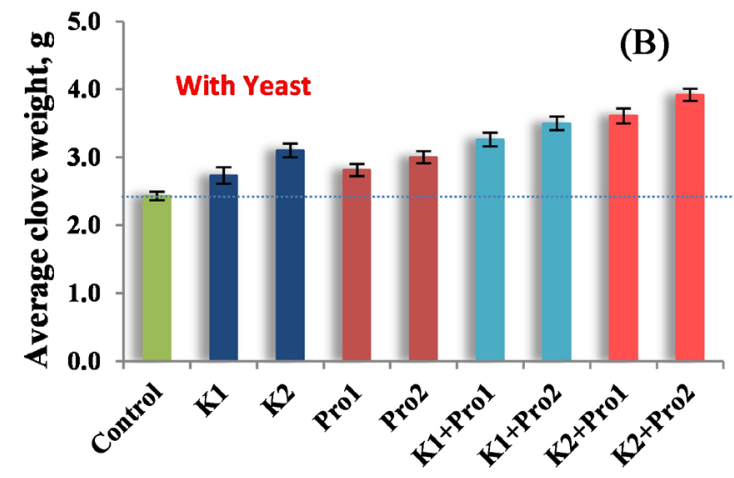

Treatments

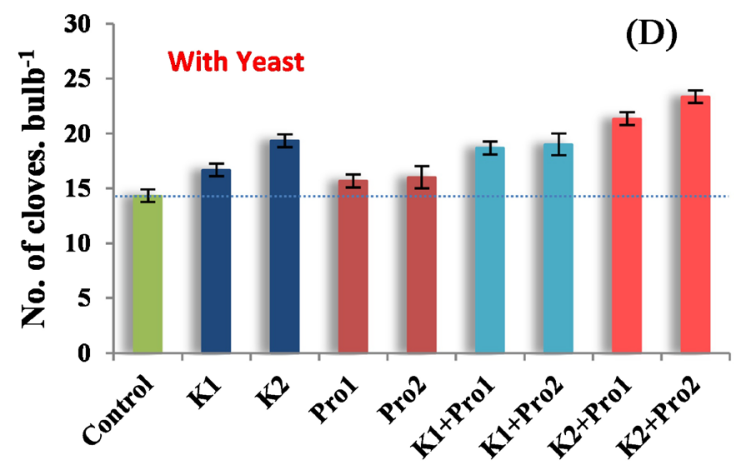

Treatments

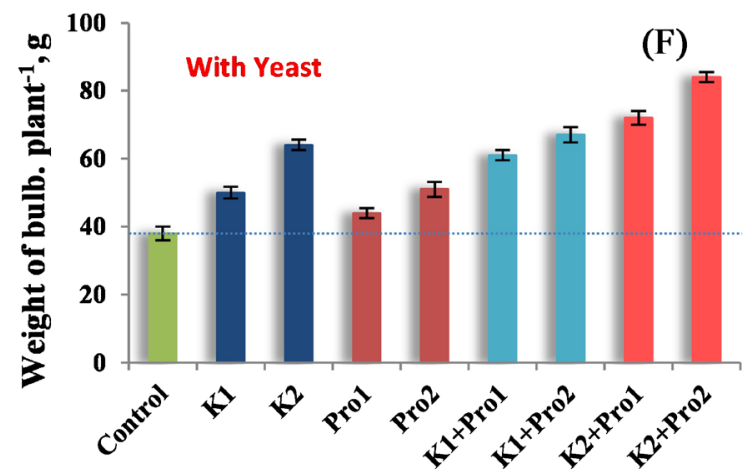

Treatments

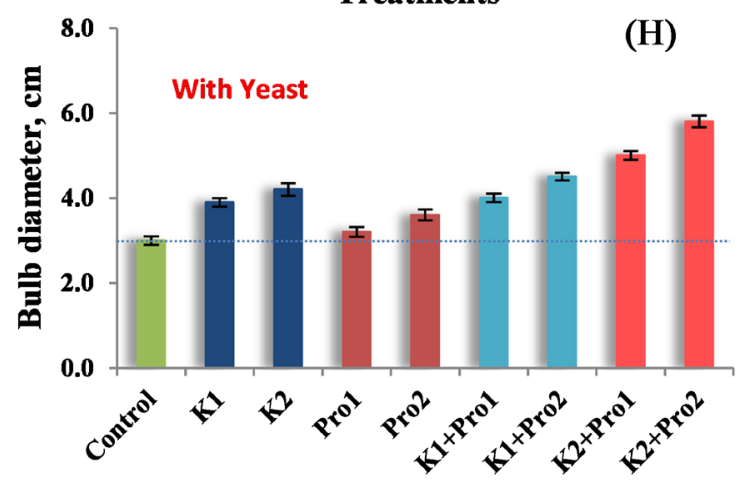

Treatments

Figure 2. Average clove weight ((A) \& (B)), number of cloves per bulb ((C) \& (D)), weight of bulb per plant ((E) \& (F)), and bulb diameter $((\mathrm{G}) \&(\mathrm{H}))$ of garlic plants at 180 days after planting time as affected by proline, $\mathrm{K}$ levels, and their interactions without yeast ((A), (C), (E) \& (G)), and with 3\% yeast ((B), (D), (F) \& (H)) during growing season. Error bars represent standard deviation of the mean. 
sprayed plant with Pro $2(50 \mathrm{mM})$, and 3\% yeast extract gave the highest values of average clove weight, number of cloves per bulb, weight of bulb per plant, and bulb diameter at harvesting time.

Jiku et al. [29] reported that the maximum total yield and size of garlic bulb were obtained with potassium application at $200 \mathrm{~kg} \cdot \mathrm{ha}^{-1}$. Potassium at 200 $\mathrm{kg} \cdot \mathrm{ha}^{-1}$ produced the highest fresh and dry weights of bulbs and leaves, diameter, moisture content, number of cloves, and yield as compared to the other treatments. It was suggested that the yield of garlic increased with increasing potassium fertilizer, where $\mathrm{K}$ application at $200 \mathrm{~kg} \cdot \mathrm{ha}^{-1}$ is suitable for obtaining maximum yield. According to Hasanuzzaman et al. [31], $\mathrm{K}$ is responsible not only for higher production but also for the improved quality of the harvest. Thus, $\mathrm{K}$ ensures high-value crops and benefits to growers. $\mathrm{K}$ is sometimes called the "quality element" for its association with better crop production, which is supported by many scientists.

Figure 3 showed that yield and its components such as total yield/fed., and relative total yield of garlic plants had significantly affected with increasing $\mathrm{K}$ levels without yeast extract (Figure 3(A) \& Figure 3(C)), and/or with 3\% yeast (Figure 3(B) \& Figure 3(D)) at harvesting time. It is obvious from current experiment that garlic plants treated with $\mathrm{K}$ level at $100 \mathrm{~kg} / \mathrm{fed}$., received sufficient level of potash and as a result, their growth was enhanced and ultimately, yield was increased.
Treatments

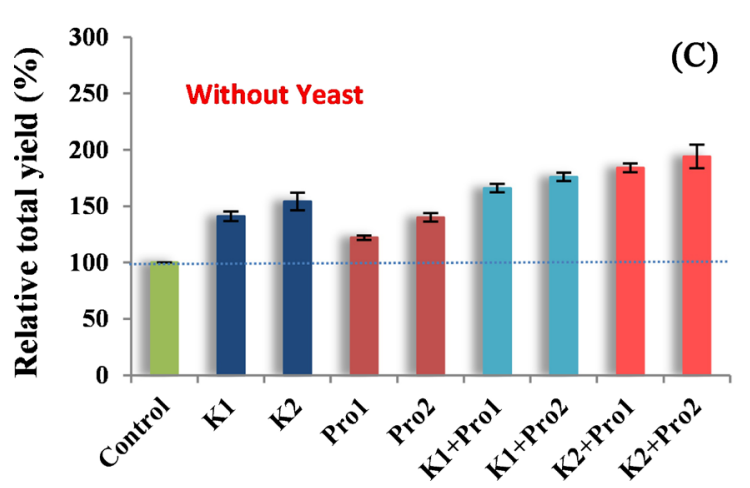

Treatments

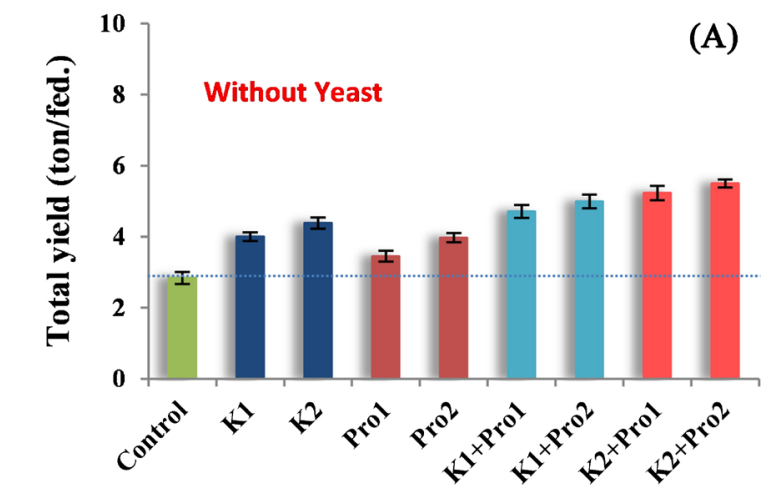

Figure 3. Total yield ((A) \& (B)), and relative total yield ((C) \& (D)) of garlic plants at 180 days after planting time as affected by proline, potassium levels, and their interactions without yeast ((A) \& (C)), and with $3 \%$ yeast ((B) \& (D)) during growing season. Error bars represent standard deviation of the mean.

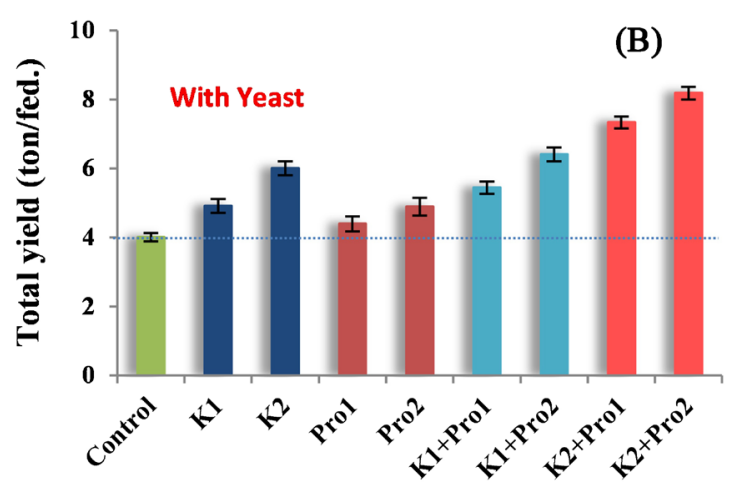

Treatments

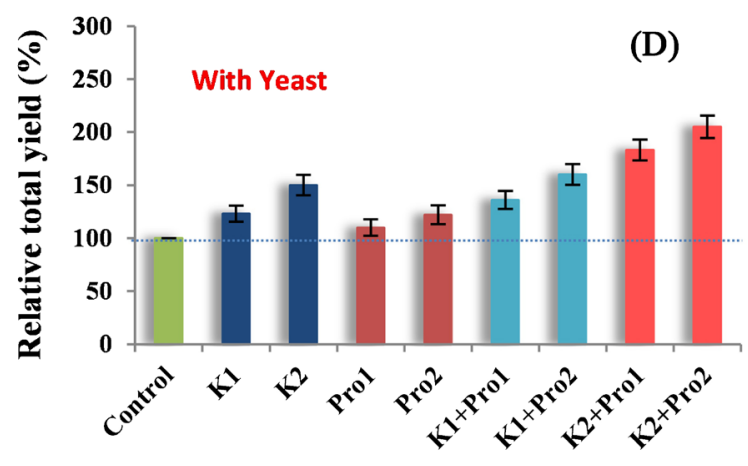

Treatments 
A sufficient supply of $\mathrm{K}$ can improve the various growth and physiological parameters of plants under normal conditions. Furthermore, $\mathrm{K}$ functions as a vital protector against abiotic stresses (e.g. salinity, drought, extreme temperature, toxic metals/metalloids, and high light) [31]. Yadav et al. [35] reported that maximum and significantly higher bulb yield of garlic was obtained with the combined application of $150 \mathrm{~kg}$ of nitrogen along with $150 \mathrm{~kg}$ of $\mathrm{K}_{2} \mathrm{O} / \mathrm{ha}$.

The present study recommends that using foliar spray with yeast extract at $3 \%$ and proline at $50 \mathrm{mM}$ combined with $\mathrm{K}$ level at $100 \mathrm{~kg} / \mathrm{fed}$., for increasing total yield per fed., of garlic plant grown under moderate saline soil.

\section{Conclusions}

The adverse environmental condition like salinity stress, which has detrimental effects on garlic crop production, can be alleviated by stress tolerance-inducing compounds, such as yeast extract and proline with proper K fertilization. Stress tolerance-inducing compounds have a remarkable ability to improve garlic plant growth and minimize the harmful effects of salinity stress without negatively affecting the environment and, ultimately, promote the ability of garlic plants to survive in moderate saline environment.

Our results revealed that the interaction between yeast extract at 3\%, foliar spray with proline at $50 \mathrm{mM}$ combined with proper $\mathrm{K}$ level at $100 \mathrm{~kg} / \mathrm{fed}$., was the best interaction treatment for increasing vegetative growth parameters, i.e. plant height, number of leaves per plant, and mineral contents (N, P, K, S, Ca and $\mathrm{Mg}$ in leaves), and proline content of garlic leaves after 135 days from planting time, and all garlic yield quality parameters including bulb quality parameters i.e. average clove weight, number of cloves per bulb, weight of bulb per plant, and bulb diameter, and also including yield and its components i.e. total yield/fed., and relative total yield of garlic plants at harvesting time.

Therefore, the interaction treatment between foliar spray with yeast extract at $3 \%$ and proline at $50 \mathrm{mM}$ combined with proper $\mathrm{K}$ level at $100 \mathrm{~kg} / \mathrm{fed}$, could be recommended for enhancing garlic plant growth, productivity, and bulb quality grown under similar conditions to this work.

\section{Conflicts of Interest}

The authors declare no conflicts of interest regarding the publication of this paper.

\section{References}

[1] Harris, J.C., Cottrell, S.L., Plummer, S. and Lloyd, D. (2001) Antimicrobial Properties of Allium sativum (Garlic). Applied Microbiology and Biotechnology, 57, 282-286. https://doi.org/10.1007/s002530100722

[2] Burian, J.P., Sacramento, L.V.S. and Carlos, I.Z. (2017) Fungal Infection Control by Garlic Extracts (Allium sativum L.) and Modulation of Peritoneal Macrophages Activity in Murine Model of Sporotrichosis. Brazilian Journal of Biology, 77, 848-855. http://dx.doi.org/10.1590/1519-6984.03716 
[3] Bisen, P.S. and Emerald, M. (2016) Nutritional and Therapeutic Potential of Garlic and Onion (Allium sp.). Current Nutrition \& Food Science, 12, 190-199. https://doi.org/10.2174/1573401312666160608121954

[4] Shabala, S. and Munns, A. (2012) Salinity Stress: Physiological Constraints and Adaptive Mechanisms. In: Shabala, S., Ed., Plant Stress Physiology, CAB International British Library, Ltd, London.

[5] Kamran, M., Parveen, A., Ahmar, S., Malik, Z., Hussain, S., Chattha, M.S., Saleem, M.H., Adil, M., Heidari, P. and Chen, J. (2020) An Overview of Hazardous Impacts of Soil Salinity in Crops, Tolerance Mechanisms, and Amelioration through Selenium Supplementation.International Journal of Molecular Sciences, 21, 148. https://doi.org/10.3390/ijms21010148

[6] Costa, S.F., Martins, D., Agacka-Mołdoch, M., Czubacka, A. and de Sousa Araújo, S. (2018) Strategies to Alleviate Salinity Stress in Plants. Salinity Responses and Tolerance in Plants, 1, 307-337. https://doi.org/10.1007/978-3-319-75671-4_12

[7] Dagar, J.C., Yadav, R.K. and Sharma, P.C. (2019) Research Developments in Saline Agriculture. Springer Nature Singapore Pte Ltd., Singapore.

https://link.springer.com/book/10.1007\%2F978-981-13-5832-6

[8] Awad-Allah, E.F.A., Gholipour, Y. and Nonami, H. (2012) Growth Promotion with Osmotic Adjustment at Low Water Potentials after $\mathrm{H}_{2} \mathrm{O}_{2}$ Pretreatment in Soybean Seeds. Environmental Control in Biology, 50, 263-276. https://doi.org/10.2525/ecb.50.263

[9] Kibria, M.G. and Hoque, M.A. (2019) A Review on Plant Responses to Soil Salinity and Amelioration Strategies. Open Journal of Soil Science, 9, 219-231. https://doi.org/10.4236/ojss.2019.911013

[10] Page, A.L., Miller, R.H. and Keeney, D.R. (1982) Methods of Soil Analysis. Part 2: Chemical and Microbiological Properties. 2nd Edition Agron. No. 9 (Part 2) in the Agronomy Series.ASA, SSSA, Inc., Madison, WI.

[11] Mclean, E.O. (1982) Soil pH and Lime Requirement. In: Page, A.L., Ed., Methods of Soil Analysis. Part 2 Chemical and Microbiological Properties, 9.2.2, 2nd Edition, ASA, SSSA, Inc., Madison, WI.

[12] Horváth, B., Opara-Nadi, O. and Beese, F. (2005) A Simple Method for Measuring the Carbonate Content of Soils. Soil Science Society of America Journal, 69, 1066-1068. http://dx.doi.org/10.2136/sssaj2004.0010

[13] Jones Jr., J.B. (2001) Laboratory Guide for Conducting Soil Tests and Plant Analysis. CRC Press, Boca Raton. https://doi.org/10.1201/9781420025293

[14] Murphy, J. and Riley, J.P. (1962) A Modified Single Solution Method for the Determination of Phosphate in Natural Waters. Analytica Chimica Acta, 27, 31-36. https://doi.org/10.1016/S0003-2670(00)88444-5

[15] USAID (2012) Guidelines for Water Reuse. U.S. Environmental Protection Agency, Washington DC.

[16] Francesca, S., Arena, C., Mele, B.H., Schettini, C., Ambrosino, P., Barone, A. and Rigano, M.M. (2020) The Use of a Plant-Based Biostimulant Improves Plant Performances and Fruit Quality in Tomato Plants Grown at Elevated Temperatures. Agronomy, 10, 363. https://doi.org/10.3390/agronomy10030363

[17] Bates, L.S., Waldren, R.P. and Teare, I.D. (1973) Rapid Determination of Free Proline for Water-Stress Studies. Plant and Soil, 39, 205-207.

https://doi.org/10.1007/BF00018060

[18] Jackson, M.L. (1967) Soil Chemical Analysis. Prentice-Hall of India Pvt. Ltd., New 
Delhi.

[19] Johnson, C.M. and Nishita, H. (1952) Microestimation of Sulfur in Plant Materials, Soils, and Irrigation Waters. Analytical Chemistry, 24,736-742.

https://doi.org/10.1021/ac60064a032

[20] Gomez, K.A. and Gomez, A.A. (1984) Statistical Procedures for Agricultural Research. 2nd Edition, John Wiley and Sons, New York.

[21] CoStat Software (2004) Microcomputer Program Analysis, Version 6.303. CoHort Software, Monterey, CA.

[22] Ganjegunte, G. and Clark, J. (2019) Causes and Management of Root-Zone Salinity and Sodicity in the Arid West Texas: Field-Scale Experience. In: Dagar, J.C., Yadav, R. and Sharma, P., Eds., Research Developments in Saline Agriculture, Springer Nature Singapore Pte Ltd., Singapore, 307-330.

https://doi.org/10.1007/978-981-13-5832-6_9

[23] Khoshgoftarmanesh, A.H., Shariatmadari, H. and Vakil, R. (2007) Reclamation of Saline Soils by Leaching and Barley Production. Communications in Soil Science and Plant Analysis, 34, 2875-2883. https://doi.org/10.1081/CSS-120025198

[24] Xi, Q., Lai, W., Cui, Y., Wu, H. and Zhao, T. (2019) Effect of Yeast Extract on Seedling Growth Promotion and Soil Improvement in Afforestation in a Semiarid Chestnut Soil Area. Forests, 10, 76. https://doi.org/10.3390/f10010076

[25] EL-Yazied, A. and Mady, M.A. (2012) Effect of Boron and Yeast Extract Foliar Application on Growth, Pod Setting and Both Green Pod and Seed Yield of Broad Bean (Viciafaba L.). Journal of Applied Sciences Research, 8, 1240-1251.

[26] Nassar, R.M.A., Shanan, N.T. and Reda, F.M. (2016) Active Yeast Extract Counteracts the Harmful Effects of Salinity Stress on the Growth of Leucaena Plant. Scientia Horticulturae, 201, 61-67. doi.org/10.1016/j.scienta.2016.01.037

[27] Abdelaal, K.A., EL-Maghraby, L.M., Elansary, H., Hafez, Y.M., Ibrahim, E.I., El-Banna, M., El-Esawi, M. and Elkelish, A. (2020) Treatment of Sweet Pepper with Stress Tolerance-Inducing Compounds Alleviates Salinity Stress Oxidative Damage by Mediating the Physio-Biochemical Activities and Antioxidant Systems. Agronomy, 10, 26. https://doi.org/10.3390/agronomy10010026

[28] Heuer, B. (2010) Role of Proline in Plant Response to Drought and Salinity. In: Pessarakli, M., Ed., Handbook of Plant and CropStress. CRC Press, Boca Raton, 213-238.

[29] Jiku, M.A., Alimuzzaman, M., Singha, A., Rahaman, M.A., Ganapati, R.K., Alam, M. A. and Sinha, S.R. (2020) Response and Productivity of Garlic (Allium sativum L.) by Different Levels of Potassium Fertilizer in Farm Soils. Bulletin of the National Research Centre, 44, 2-9. https://doi.org/10.1186/s42269-020-0267-7

[30] Castellanos, J.Z., Ojodeagua, J.L., Méndez, F., Alcantar, G., Villalobos-Reyes, S., Vargas, P., Muñoz-Ramos, J.J. and Lazcano-Ferrat, I. (2002) Potassium Requirements for Garlic under Fertigation. Better Crops International, 16, 9-11.

[31] Hasanuzzaman, M., Bhuyan, M.H.M.B., Nahar, K., Hossain, M.S., Al Mahmud, J., Hossen, M.S., Masud, A.A.C., Moumita and Fujita, M. (2018) Potassium: A Vital Regulator of Plant Responses and Tolerance to Abiotic Stresses. Agronomy, 8, 31. https://doi.org/10.3390/agronomy8030031

[32] El-Ramady, H., Alshaal, T., Elhawat, N., Ghazi, A., Elsakhawy, T., Omara, A.E., El-Nahrawy, S., Elmahrouk, M., Abdalla, N., Domokos-Szabolcsy, E. and Schnug, E. (2018) Plant Nutrients and Their Roles under Saline Soil Conditions. In: Hasanuzzaman, M., Fujita, M., Oku, H., Nahar, K. and Hawrylak-Nowak, B., Eds., Plant 
Nutrients and Abiotic Stress Tolerance, Springer, Singapore, 297-324.

https://doi.org/10.1007/978-981-10-9044-8_13

[33] Verbruggen, N. and Hermans, C. (2008) Proline Accumulation in Plants: A Review. Amino Acids, 35, 753-759. https://doi.org/10.1007/s00726-008-0061-6

[34] Hayat, S., Hayat, Q., Alyemeni, M.N., Wani, A.S., Pichtel, J. and Ahmad, A. (2012) Role of Proline under Changing Environments: A Review. Plant Signaling \& Behavior, 7, 1456-1466. https://doi.org/10.4161/psb.21949

[35] Yadav, R.S., Sammauria, R. and Rathore, M.S. (2007) Effect of Nitrogen and Potassium on the Growth, Yield and Quality of Garlic (Allium sativum) in Light Textured Soils of Rajasthan. Indian Journal of Agricultural Sciences, 77, 168-169. 